\title{
Atypical coexistence of polymorphic light eruption and eruptive lichen planus in a patient with necrobiosis lipoidica
}

\author{
Nietypowe współwystępowanie wielopostaciowych osutek świetlnych \\ i liszaja płaskiego wysiewnego u pacjentki z obumieraniem tłuszczowatym
}

\author{
Weronika Buczyńska', Agnieszka Popow', Julia Nowowiejska², Anna Baran², Iwona Flisiak² \\ 'Student Research Club at the Department of Dermatology and Venereology, Medical University of Bialystok, Bialystok, Poland \\ ${ }^{2}$ Department of Dermatology and Venereology, Medical University of Bialystok, Bialystok, Poland Country
}

'Studenckie Koło Naukowe przy Klinice Dermatologii i Wenerologii, Uniwersytet Medyczny, Białystok, Polska ${ }^{2}$ Klinika Dermatologii i Wenerologii, Uniwersytet Medyczny, Białystok, Polska

\author{
CORRESPONDING AUTHOR/ \\ ADRES DO KORESPONDENCJI: \\ dr n. med. Julia Nowowiejska \\ Klinika Dermatologii \\ i Wenerologii \\ Uniwersytet Medyczny \\ Białystok, Polska \\ tel.: +48 607130193 \\ e-mail: julia.nowowiejska@umb. \\ edu.pl
}

\begin{abstract}
Introduction: Polymorphic light eruption is a photodermatosis characterised by an erythematous, papular and vesicular rash developing in areas exposed to UV radiation. Lichen planus in the eruptive variant presents with diffuse polygon-shaped papules accompanied by pruritus. Necrobiosis lipoidica manifests as yellow-brown atrophic plaques with central telangiectasias, typically located on the lower legs.

Objective: Presentation of a case of atypical coexistence of polymorphous light eruption, eruptive lichen planus, and necrobiosis lipoidica.

Case report: A 59-year-old woman with a history of necrobiosis lipoidica involving the skin of both lower extremities was admitted to the Department of Dermatology for the diagnosis work-up of skin lesions that appeared 2 weeks earlier. Confluent erythematous and papular lesions were observed on the skin of the neck, chest, shoulders, and back. Additionally, diffuse pruritic papules were noted within the upper and lower extremities and in the sacral region. The histopathological features of a skin sample taken from the back and forearm were consistent with polymorphous light eruption and lichen planus, respectively. Clobetasol and antihistamines were used, leading to an improvement in skin condition.

Conclusions: Simultaneous occurrence of the three dermatoses mentioned above is an uncommon phenomenon, and may be diagnostically challenging. Consequently, effective diagnostic management should incorporate histopathological examination in correlation with the clinical presentation and comprehensive anamnesis.
\end{abstract}

Key words: polymorphous light eruption, eruptive lichen planus, necrobiosis lipoidica, Koebner phenomenon.

\section{STRESZCZENIE}

Wprowadzenie: Wielopostaciowe osutki świetlne to fotodermatoza, charakteryzująca się osutką rumieniowo-grudkowo-pęcherzykową $\mathrm{w}$ okolicach eksponowanych na promieniowanie UV. Liszaj płaski w postaci wysiewnej objawia się wielobocznymi, rozsianymi grudkami z towarzyszącym świądem. W obumieraniu tłuszczowatym występu- 
ją żółtobrązowe, atroficzne blaszki z teleangiektazjami w centrum, zazwyczaj na podudziach.

Cel pracy: Przedstawienie przypadku nietypowego współwystępowania wielopostaciowej osutki świetlnej, wysiewnego liszaja płaskiego oraz obumierania tłuszczowatego.

Opis przypadku: Pacjentka, lat 59, z wywiadem obumierania tłuszczowatego w obrębie obu podudzi, została przyjęta do Kliniki Dermatologii w celu diagnostyki zmian skórnych występujących od 2 tygodni. Na skórze szyi, dekoltu, ramion i pleców obserwowano zlewne zmiany rumieniowo-grudkowe, na skórze kończyn górnych i dolnych oraz w okolicy krzyżowej rozsiane grudki, którym towarzyszył świąd. Obraz histopatologiczny wycinka pobranego z pleców odpowiadał wielopostaciowej osutce świetlnej, a z przedramienia liszajowi płaskiemu. Zastosowano klobetazol i leki przeciwhistaminowe, uzyskując poprawę stanu skóry.

Wnioski: Jednoczesne występowanie powyższych trzech różnych dermatoz jest nietypowe i może sprawiać trudności diagnostyczne. Cennym elementem postępowania diagnostycznego jest badanie histopatologiczne w korelacji z obrazem klinicznym i rzetelnym wywiadem.

Słowa kluczowe: wielopostaciowe osutki świetlne, liszaj płaski wysiewny, obumieranie tłuszczowate, objaw Köbnera.

\section{INTRODUCTION}

Polymorphic light eruption (PMLE) is the most common type of photodermatosis, prevalent particularly among young women living in temperate climate zones $[1,2]$. The disease is characterized by the intermittent occurrence of non-scarring, itchy, polymorphic erythematous-papular-vesicular rash or plaques in areas exposed to ultraviolet (UV) radiation [3].

Lichen planus (LP) is a dermatosis that occurs in about $1 \%$ of the population and usually affects middleaged individuals [4]. In its classic presentation, LP is characterised by red-purple, flat polygon-shaped papular skin lesions with concomitant pruritus [5]. LP lesions are usually located on the flexural surfaces of the upper and lower extremities, and occur bilaterally and relatively symmetrically [6]. Characteristic features of the condition include Wickham striae (whitish streaks visible on the papular surface) and Koebner phenomenon $[7,8]$. Lichen planus in the eruptive variant presents with multiple skin lesions, sometimes occupying a large area, typically with facial sparing [9]. LP tends to run a chronic and recurrent course [5].

Necrobiosis lipoidica (NL) is a rare granulomatous disease that predominantly affects women. The mean age of onset is between 25 and 46 years [10-12]. Clinically, NL is characterised by well-circumscribed yellow-brown plaques with central telangiectasias, typically occurring on the skin of the lower legs [10].

\section{WPROWADZENIE}

Wielopostaciowe osutki świetlne (polymorphic light eruptions - PMLE) są najczęstszą fotodermatozą, szczególnie rozpowszechnioną wśród młodych kobiet, mieszkających w klimacie umiarkowanym [1, 2]. Choroba charakteryzuje się okresowym występowaniem swędzącej, wielopostaciowej, niebliznowaciejącej osutki rumieniowo-grudkowo-pęcherzykowej lub blaszek pojawiających się w okolicach eksponowanych na działanie promieniowania ultrafioletowego (UV) [3].

Liszaj płaski (lichen planus - LP) jest dermatozą występującą u około $1 \%$ populacji, dotyczącą zwykle osób w średnim wieku [4]. Klasyczny obraz tej choroby w obrębie skóry gładkiej obejmuje występowanie wielobocznych, płaskich, sinofioletowych grudek z towarzyszącym świądem [5]. Zmiany zazwyczaj lokalizują się na zgięciowych powierzchniach kończyn górnych i dolnych, występują obustronnie i dość symetrycznie [6]. Charakterystycznymi cechami są siateczka Wickhama - białawe linie na powierzchni grudek - oraz objaw Köbnera [7, 8]. Liszaj płaski w odmianie wysiewnej charakteryzuje się obecnością licznych wykwitów zajmujących niekiedy znaczną powierzchnię, zwykle z zaoszczędzeniem twarzy [9]. Ma on zazwyczaj przebieg przewlekły i nawracający [5].

Obumieranie tłuszczowate (necrobiosis lipoidica - NL) jest rzadką chorobą ziarniniakową, która typowo dotyczy kobiet w wieku 25-46 lat [10-12]. Klinicznie NL 


\section{OBJECTIVE}

Presentation of a case of atypical coexistence of polymorphic light eruption, eruptive lichen planus, and necrobiosis lipoidica.

\section{CASE REPORT}

A 59-year-old female patient with a history of NL persisting for 8 years, monitored on an outpatient basis, was admitted to the Department of Dermatology for the diagnosis and treatment of skin lesions exhibiting two distinct types of morphological features, which appeared 2 weeks previously. One type of lesions, erythematous-papular and erythematous-oedematous eruption, was observed in the areas exposed to UV radiation: on the neck, nape, and upper back as well as confluent lesions within the upper chest (fig. 1). The other type of skin lesions, presenting as eruptive polygon-shaped pink-red, glossy papules, and exhibiting Koebner phenomenon, appeared on the skin of the upper and lower extremities, and in the sacral region (fig. 2). The lesions were accompanied by pruritus. In addition, extensive, well-circumscribed, yellowbrown plaques with atrophy and telangiectasias in the centre were noted on the extensor surfaces of both lower legs, consistent with a typical presentation of NL (fig. 3). Within the NL foci, erosion was seen on one lower leg, and ulceration on the other. Laboratory tests demonstrated no significant abnormalities. No antibodies were detected in an antinuclear antibody panel (ANA-3). Similarly, no anti-HCV antibodies were identified. Two skin samples were taken for histopathological examination - from the lesions on the back and forearm. Based on the microscopic features of the examined skin specimens, in correlation with the

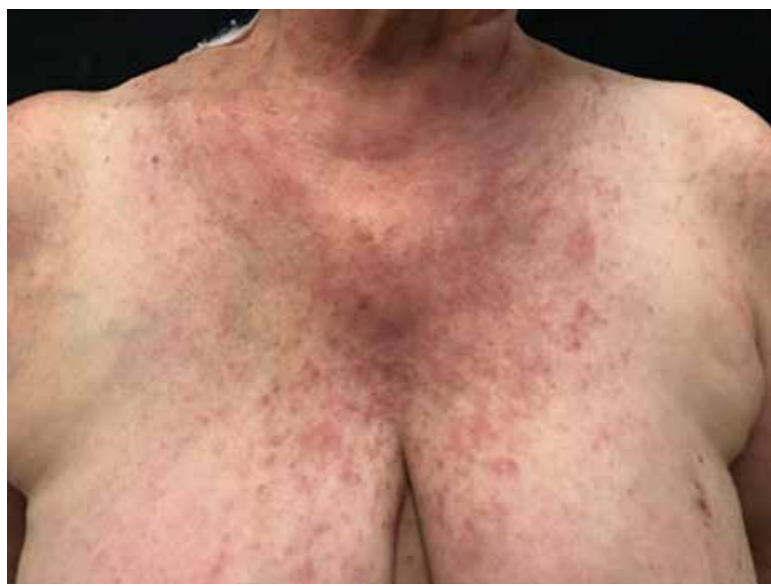

Figure I. Confluent erythematous-papular eruptions on the skin of the neck and upper chest

Rycina I. Zlewne zmiany o charakterze rumieniowo-grudkowym zlokalizowane w obrębie skóry szyi i klatki piersiowej typowo występuje na podudziach i cechuje się żółtobrązowymi, dobrze odgraniczonymi blaszkami z teleangiektazjami w części centralnej [10].

\section{CEL PRACY}

Przedstawienie opisu przypadku nietypowego współwystępowania wielopostaciowych osutek świetlnych, liszaja płaskiego wysiewnego oraz obumierania tłuszczowatego.

\section{OPIS PRZYPADKU}

Pacjentka, lat 59, z wywiadem NL od 8 lat, będąca pod kontrolą ambulatoryjną została przyjęta do Kliniki Dermatologii w celu diagnostyki i leczenia zmian skórnych o dwóch odmiennych typach morfologii, które pojawiły się przed 2 tygodniami. Pierwszy typ zmian, rumieniowo-grudkowych i rumieniowo-obrzękowych, obserwowano w okolicach eksponowanych na promieniowanie UV - w obrębie szyi, karku, górnej części pleców oraz klatki piersiowej w okolicy mostka (w rzucie dekoltu) (ryc. 1.). Drugi rodzaj zmian, w postaci wysiewnych, wielobocznych, różowoczerwonych, połyskliwych grudek, z widocznym objawem Köbnera pojawił się w obrębie kończyn górnych i dolnych oraz w okolicy krzyżowej (ryc. 2.). Zmianom towarzyszył

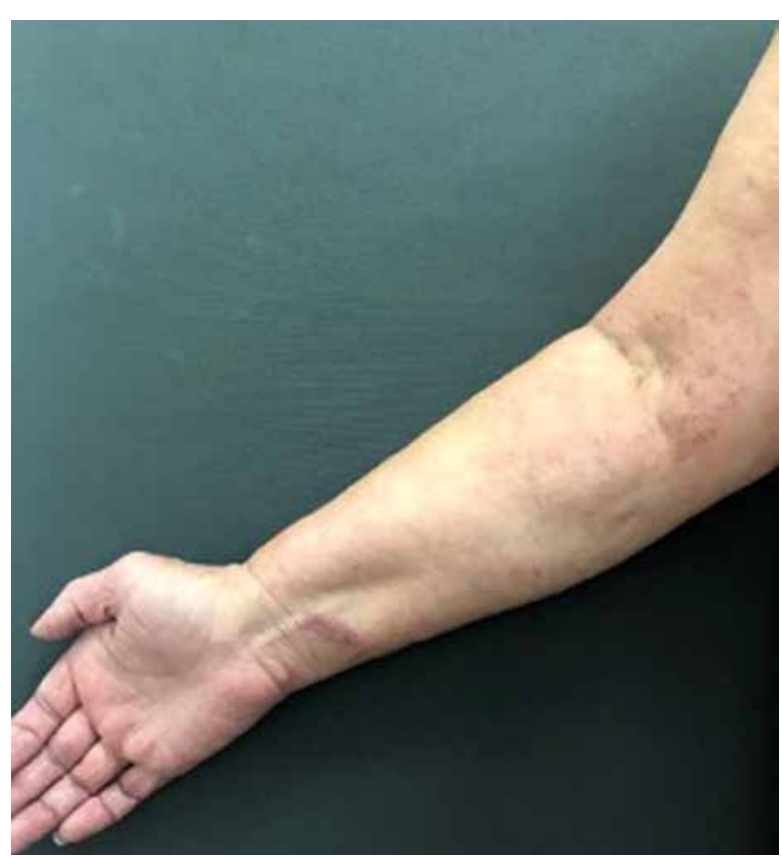

Figure 2. Diffuse pink-red papules on the skin of the right upper limb, with Koebner phenomenon in the wrist area

Rycina 2. Zmiany w postaci rozsianych, różowoczerwonych grudek zlokalizowane na skórze kończyny górnej prawej wraz z widocznym objawem Köbnera w okolicy nadgarstka 


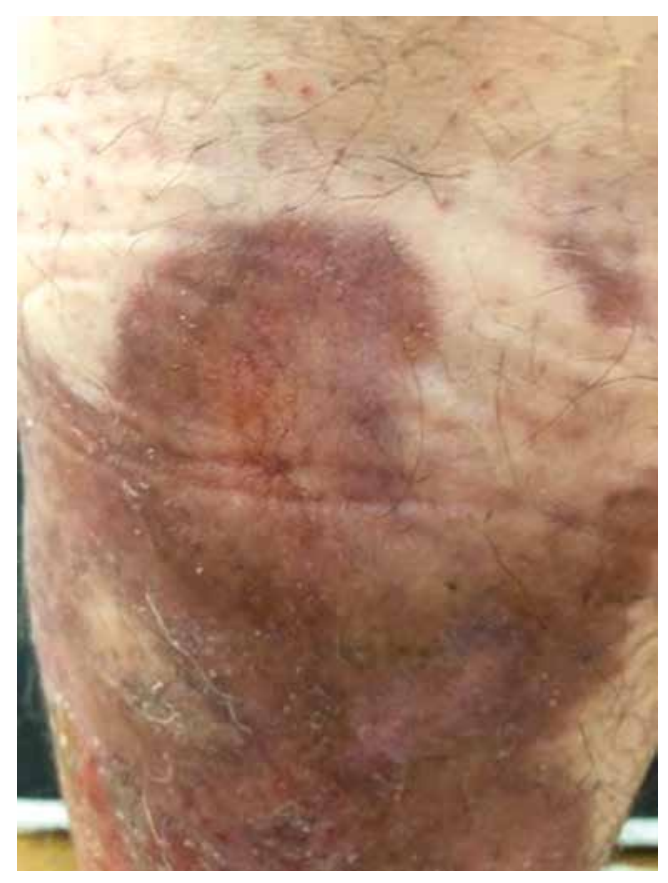

Figure 3. Well-circumscribed, yellow-brown plaques with atrophy and telangiectasias in the centre, located on the skin of the lower legs

Rycina 3. Dobrze odgraniczone żótto-brązowe blaszki z atrofią i teleangiektazjami w części centralnej zlokalizowane w obrębie skóry podudzi

clinical presentation, the patient was diagnosed with PMLE and eruptive LP. For therapeutic management, topical clobetasol ointment and emollients were used. In addition, sulphathiazole silver, and hydrogel and hydrocolloid dressings were applied on the NL foci. Antihistamine drugs were used for systemic therapy. After the treatment, the patient's skin condition improved significantly, and she was discharged home with the instruction to report for further follow-up at the Dermatology Outpatient Clinic.

\section{DISCUSSION}

To the best of our knowledge, no similar cases of NL, LP and PMLE coexisting in a single patient have been reported in the literature to date.

In our patient, erythematous-papular lesions occurring in UV-exposed skin areas were consistent with PMLE [13]. The aetiology of this dermatosis is unknown, but it has been hypothesised that genetic factors or a delayed hypersensitivity reaction to an endogenous - as yet unidentified - antigen arising from exposure to UV radiation might be implicated [14]. The currently recommended first-line treatment is based on topical glucocorticosteroids and photoprotection, while systemic glucocorticosteroids and phototherapy are normally prescribed as second-line therapy. The latest publications also contain reports on the therapeutic świąd. Ponadto na wyprostnych powierzchniach obu podudzi występowały rozległe, dobrze odgraniczone, żółtobrązowe blaszki z zanikiem i teleangiektazjami w części centralnej, odpowiadające typowemu obrazowi NL (ryc. 3.). W obrębie ognisk NL na jednym z podudzi widoczna była nadżerka, a na drugim owrzodzenie. $W$ badaniach laboratoryjnych nie stwierdzono istotnych odchyleń od normy. Wynik badania ANA3 był negatywny. Nie wykazano także przeciwciał anty-HCV. Pobrano dwa wycinki do badania histopatologicznego: ze zmian na plecach oraz z przedramienia. Na podstawie obrazu histopatologicznego pobranych wycinków w korelacji z obrazem klinicznym ustalono rozpoznanie PMLE oraz wysiewnego LP. W postępowaniu terapeutycznym zastosowano miejscowo maść z klobetazolem oraz emolienty, a na ogniska NL sól srebrową sulfatiazolu oraz opatrunki hydrożelowe i hydrokoloidowe. W leczeniu ogólnym włączono leki przeciwhistaminowe. Po zastosowanym leczeniu uzyskano znaczną poprawę stanu skóry i pacjentkę wypisano do domu z zaleceniem dalszej kontroli w poradni dermatologicznej.

\section{OMÓWIENIE}

Według naszej wiedzy dotychczas w piśmiennictwie nie opisano podobnego przypadku współwystępowania NL, LP i PMLE u jednego pacjenta.

U przedstawionej chorej zmiany rumieniowo-grudkowe występujące w okolicach eksponowanych na promieniowanie UV odpowiadały PMLE [13]. Etiologia tej dermatozy nie jest znana, jednak podejrzewana jest rola czynników genetycznych lub opóźnionej reakcji nadwrażliwości na endogenny, niepoznany dotąd antygen, powstający po ekspozycji na promieniowanie UV [14]. W leczeniu, w pierwszej kolejności zaleca się miejscowe glikokortykosteroidy oraz fotoprotekcję. Leczeniem drugiego wyboru są stosowane ogólnie glikokortykosteroidy oraz fototerapia. W najnowszych publikacjach można znaleźć także doniesienia o skutecznym zastosowaniu azatiopryny lub cyklosporyny A oraz leków przeciwmalarycznych, a także suplementacji kwasami omega-3 i beta-karotenu [3].

W literaturze opisuje się silną korelację pomiędzy występowaniem wysiewnego LP z zakażeniami wirusami hepatotropowymi, szczególnie wirusem zapalenia wątroby typu C (HCV) [4-6]. W stosunku do populacji ogólnej u pacjentów zakażonych HCV występuje istotnie większe ryzyko rozwoju LP, jednak badania w tym kierunku wykazują duże rozbieżności w zależności od położenia geograficznego [15]. Stwierdzono, że HCV namnaża się w skórze oraz błonach śluzowych, co prowadzi do wystąpienia związanego z infekcją LP. Interesujący jest fakt, że związek LP i HCV zwiększa ryzyko transformacji nowotworo- 
benefits associated with azathioprine or cyclosporin A and antimalarial drugs, as well as supplementation with omega- 3 acids and beta carotene [3].

A strong correlation has been described in the literature between the development of eruptive LP and hepatotropic virus infections, particularly the hepatitis $\mathrm{C}$ virus (HCV) [4-6]. Compared to the general population, HCV-infected patients are at a significantly higher risk of developing LP, however, studies investigating this link show large discrepancies depending on the geographical region [15]. HCV has been shown to proliferate in the skin and mucous membranes, resulting in infection-related LP. Interestingly, this aetiology of LP increases the risk of malignant transformation compared to LP developing without an underlying HCV infection [16]. However, HCV infection was ruled out in the reported patient. In addition, she did not take any medications known to predispose towards the development of LP, such as angiotensin-converting enzyme inhibitors, antimalarials, $\beta$-blockers, allopurinol, or non-steroidal anti-inflammatory drugs [4]. Genetic and environmental factors (stress, depression) have also been suggested as potential causes of the disease, but the pathogenesis is still not fully understood [4]. The patient denied any stressful events preceding the eruption of skin lesions, and had no underlying psychiatric conditions, so the specific trigger for the dermatosis could not be established. Some authors have observed a higher incidence of glucose metabolism disorders in patients with LP. However, study findings show a large discrepancy in the coexistence of these conditions depending on age and sex. In addition, many of the available analyses do not distinguish between type 1 and type 2 diabetes mellitus [17, 18]. The suspected immune mechanism underlying LP and diabetes may explain the observed increased prevalence of both conditions coexisting in the same patient $[15,18,19]$. Some authors have linked the more frequent coexistence of LP and diabetes mellitus to the hypoglycaemic drugs taken by patients, as the lesions arising during treatment may be clinically consistent with the features of LP $[18,20]$. However, in the reported patient carbohydrate metabolism disorders were excluded.

The woman's extensive NL lesions exemplify the classic features of this dermatosis, however, the ulceration and erosions are known to appear far less frequently in women [21]. NL has strong links with diabetes mellitus and impaired glucose tolerance, but no such disorders occurred in the reported patient [22]. Various studies have shown coexisting diabetes in $30-60 \%$ of patients diagnosed with NL [10]. On the other hand, only $3 \%$ of diabetics develop symptoms of NL [10]. The aetiopathogenesis of the disease has been hypothesised to involve vascular disorders caused by the deposition of immune complexes and microangiopathic changes leading to collagen degeneration wej w porównaniu z LP niezwiązanym z HCV [16]. U prezentowanej pacjentki zakażenie HCV zostało wykluczone. Kobieta nie przyjmowała również leków predysponujących do wystąpienia LP, takich jak inhibitory konwertazy angiotensyny, leki przeciwmalaryczne, $\beta$-adrenolityki, allopurynol lub niesteroidowe leki przeciwzapalne [4]. Jako potencjalne przyczyny liszaja płaskiego wymieniane są również czynniki genetyczne oraz środowiskowe (stres, depresja), jednak jej patogeneza do dziś nie jest do końca poznana [4]. Pacjentka negowała sytuacje stresowe poprzedzające wysiew zmian, nie miała również chorób psychicznych, dlatego konkretny czynnik wyzwalający dermatozę nie został ustalony. Niektórzy autorzy zaobserwowali częstsze występowanie zaburzeń metabolizmu glukozy u pacjentów z LP, jednak wyniki badań prezentują dużą rozbieżność we współwystępowaniu tych jednostek chorobowych, a wiele $z$ analiz nie rozróżnia typu 1. i 2. cukrzycy $[17,18]$. Podejrzewane immunologiczne podłoże LP i cukrzycy może tłumaczyć częstsze współwystępowanie tych jednostek [15, 18, 19]. Część autorów wiąże częstsze współwystępowanie LP i cukrzycy z lekami hipoglikemizującymi przyjmowanymi przez pacjentów, gdyż powstające podczas leczenia zmiany klinicznie mogą być zgodne z obrazem LP [18, 20]. U opisywanej pacjentki zaburzenia gospodarki węglowodanowej zostały jednak wykluczone.

Obecne $\mathrm{u}$ kobiety rozległe zmiany $\mathrm{w}$ postaci NL stanowią klasyczny obraz tej dermatozy, jednak stwierdzone owrzodzenie i nadżerki pojawiają się znacznie rzadziej u kobiet [21]. NL jest silnie powiązane z występowaniem cukrzycy i nieprawidłową tolerancją glukozy, jednak u przedstawionej pacjentki nie występowały takie zaburzenia [22]. Różne badania wykazały występowanie cukrzycy podczas diagnozy NL u 30-60\% pacjentów [10]. Tylko u 3\% diabetyków występują objawy NL [10]. W etiopatogenezie tej choroby brane są pod uwagę zaburzenia naczyniowe spowodowane odkładaniem kompleksów immunologicznych oraz zmiany mikroangiopatyczne prowadzące do degeneracji kolagenu [12, 21]. Obecnie w praktyce klinicznej wciąż nie ma wystandaryzowanego i skutecznego leczenia wrzodziejącego NL. Terapia pierwszego wyboru obejmuje kontrolę czynników ryzyka sercowo-naczyniowego oraz miejscowo stosowane glikokortykosteroidy i iniekcje glikokortykosteroidów doogniskowo. Inne metody to: glikokortykosteroidy stosowane ogólnie, miejscowe inhibitory kalcyneuryny i leki immunomodulujące. W piśmiennictwie znane są również doniesienia o skuteczności terapii PUVA, terapii fotodynamicznej oraz terapii laserem pulsacyjnym barwnikowym. Stosowane są również leki biologiczne $\mathrm{z}$ grupy anty-TNF i inhibitory kinaz janusowych. Opisano również korzystny efekt zastosowania przeszczepu tkankowego wraz z miejscowym podaniem sewofluranu [10, 21, 23]. 
$[12,21]$. There is, as yet, no standardised effective treatment for ulcerative NL in the current clinical practice. First-line therapy consists of the management of cardiovascular risk factors, topical glucocorticosteroids, and intralesional injections of glucocorticosteroids. Other therapies include systemic glucocorticosteroids, topical calcineurin inhibitors, and immunomodulatory drugs. There are also literature reports on the efficacy of PUVA therapy, photodynamic therapy, and pulsed dye laser therapy. Another available therapeutic modality is based on biologic drugs from the group of anti-TNF and Janus kinase inhibitors. Treatment benefits have also been noted after a tissue graft followed by the topical administration of sevoflurane [10, 21, 23].

Studies suggest that both LP and NL may serve as specific prognostic factors for the future development of diabetes mellitus [24]. The same study described the coexistence of NL and LP in two diabetic patients [24]. Interestingly, as in LP, Koebner phenomenon can be observed in NL [21].

Even though the exact aetiopathogenesis of the above diseases is not yet known, their inflammatory component has been described in the literature, which makes them sensitive to treatment with topical glucocorticosteroids $[3,21,25,26]$. These drugs, through their vasoconstrictive effect, promote a reduced influx of cytokines and inflammatory cells, which is of relevance in all these diseases [27]. In PMLE, they additionally have antioedematous properties and inhibit a delayed hypersensitivity reaction [27]. Potent topical glucocorticosteroids are used to reduce pruritus both in LP and PMLE [28, 29].

\section{CONCLUSIONS}

The patient presented with atypical coexistence of NL, PMLE and eruptive LP, which is an extremely rare phenomenon, and difficult to explain. Nevertheless, it is important to note that cases such as this one may be associated with a delay in making the correct diagnosis. The aetiology of these conditions is not fully understood, but a varying pathogenesis is suspected. Despite that, an effective first-line treatment modality is the same in all these dermatoses, and involves topical glucocorticosteroids. A key role is attributed to patients' detailed medical history, physical examination, diagnostic work-up to determine possible comorbidities, and histopathological examination, which is decisive.

\section{CONFLICT OF INTEREST}

The authors declare no conflict of interest.
Badania sugerują, że zarówno LP, jak i NL mogą służyć jako czynniki prognostyczne rozwoju cukrzycy w przyszłości [24]. W tym samym badaniu opisano jednoczesne współwystępowanie NL oraz LP u dwóch pacjentów z cukrzycą [24]. Co ciekawe, podobnie jak w przypadku LP, w NL możliwe było zaobserwowanie objawu Köbnera [21].

Dokładna etiopatogeneza powyższych chorób nie jest dokładnie poznana. W piśmiennictwie opisywanym wspólnym czynnikiem patogenetycznym jest kompotent zapalny, co warunkuje skuteczność miejscowo stosowanych glikokortykosteroidów w leczeniu powyższych schorzeń [3, 21, 25, 26]. Leki te poprzez wazokonstrykcję sprzyjają zmniejszonemu napływowi cytokin oraz komórek zapalnych, co ma znaczenie we wszystkich tych chorobach [27]. W PMLE dodatkowo działają przeciwobrzękowo oraz hamują opóźnioną reakcję nadwrażliwości [27]. Silne glikokortykosteroidy stosowane miejscowo są wykorzystywane w celu zmniejszenia świądu zarówno w LP, jak i PMLE $[28,29]$.

\section{WNIOSKI}

U pacjentki stwierdzono niezwykle rzadkie i trudne do wyjaśnienia współwystępowanie NL, PMLE i LP, co potencjalnie może się wiązać z opóźnieniem postawienia prawidłowej diagnozy. Etiologia tych chorób nie jest do końca poznana, lecz podejrzewana jest odmienna patogeneza. Zazwyczaj leczeniem pierwszego wyboru we wszystkich opisanych jednostkach chorobowych są miejscowo stosowane glikokortykosteroidy. Kluczowe są rzetelne badanie podmiotowe, przedmiotowe, diagnostyka w kierunku możliwych schorzeń współistniejących oraz badanie histopatologiczne, które jest rozstrzygające.

\section{KONFLIKT INTERESÓW}

Autorzy nie zgłaszają konfliktu interesów. 
References

Piśmiennictwo

1. Gruber-Wackernagel A., Hofer A., Legat F., Wolf P.: Frequency of occurrence of polymorphic light eruption in patients treated with photohardening and patients treated with phototherapy for other diseases. Photodermatol Photoimmunol Photomed 2019, 35, 100-105.

2. Karthikeyan K., Aishwarya M.: Polymorphous light eruption - an Indian scenario. Indian Dermatol Online J 2021, 12, $211-219$.

3. Lembo S., Raimondo A.: Polymorphic light eruption: what's new in pathogenesis and management. Front Med 2018, 5, 252.

4. Tziotzios C., Lee J.Y.W., Brier T., Saito R., Hsu C.K., Bhargava K., et al.: Lichen planus and lichenoid dermatoses. J Am Acad Dermatol 2018, 79, 789-804.

5. Lehman J.S., Tollefson M.M., Gibson L.E.: Lichen planus. Int J Dermatol 2009, 48, 682-694.

6. Gorouhi F., Davari P., Fazel N.: Cutaneous and mucosal lichen planus: a comprehensive review of clinical subtypes, risk factors, diagnosis, and prognosis. ScientificWorldJournal 2014, 2014, 742826. doi: 10.1155/2014/742826.

7. Steffen C., Dupree M.L.: Louis-Frédéric Wickham and the Wickham's striae of lichen planus. Skinmed 2004, 3, 287-289.

8. Sagi L., Trau H.: The Koebner phenomenon. Clin Dermatol 2011, 29, 231-236.

9. Vogt T.: Liszaj płaski. [In:] Braun-Falco Dermatologia. W. Gliński (ed.), Czelej, Lublin, 2010, 547-552.

10. Peckruhn M., Tittelbach J., Elsner P.: Update: treatment of necrobiosis lipoidica. J Dtsch Dermatol Ges 2017, 15, 151-157.

11. Imadojemu S., Rosenbach M.: Advances in inflammatory granulomatous skin diseases. Dermatol Clin 2019, 37, 49-64.

12. Ciążyńska M., Bednarski I., Narbutt J., Woźniacka A., Lesiak A.: Obumieranie tłuszczowate nadal wyzwaniem terapeutycznym. Przegl Dermatol 2016, 103, 45-48.

13. Lehmann P., Schwarz T.: Photodermatoses: diagnosis and treatment. Dtsch Arztebl Int 2011, 108, 135-141.

14. Guarrera M.: Polymorphous light eruption. Adv Exp Med Biol 2017, 996, 61-70.

15. Nosratzehi T.: Oral lichen planus: an overview of potential risk factors, biomarkers and treatments. Asian Pac J Cancer Prev 2018, 19, 1161-1167.

16. Nagao Y., Kawasaki K., Sata M.: Insulin resistance and lichen planus in patients with HCV-infectious liver diseases. J Gastroenterol Hepatol 2008, 23, 580-585.

17. Grinspan D., Diaz J., Villapol L.O., Schneiderman J., Berdichesky R., Palèse D., et al.: Lichen ruber planus of the buccal mucosa. Its association with diabetes. Bull Soc Fr Dermatol Syphiligr 1966, 73, 898-899.

18. Nigam P.K., Sharma L., Agrawal J.K., Singh G., Khurana S.K.: Glucose tolerance studies in lichen planus. Dermatology 1987, $175,284-289$

19. Seyhan M., Özcan H., Sahin I., Bayram N., Karincaoğlu Y.: High prevalence of glucose metabolism disturbance in patients with lichen planus. Diabetes Res Clin Pract 2007, 77, 198-202.

20. Grabowska-Szeląg K., Tomera-Niekowal I., Kęsek B.: Lichen planus coexisting with diabetes mellitus and hypertension (Grinspan's syndrome) - description of two cases. J Stoma 2018, 71, 449-456.

21. Sibbald C., Reid S., Alavi A.: Necrobiosis lipoidica. Dermatol Clin 2015, 33, 343-360.

22. Grillo E., Rodriguez-Muñoz D., González-Garcia A., Jaén P.: Necrobiosis lipoidica. Aust Fam Physician 2014, 43, 129-130.

23. Quintana-Castanedo L., Recarte-Marín L., Pérez-Jerónimo L., Conde-Montero E., de la Cueva-Dobao P.: Ulcerative necrobiosis lipoidica diabeticorum successfully treated with topical sevoflurane and punch grafting. Int Wound J 2019, 16, 1234-1236.

24. Jolly M.: Lichen planus and its association with diabetes mellitus. Med J Aust 1972, 19, 990-992.

25. Barnes P.J.: Glucocorticosteroids. Handb Exp Pharmacol 2017, 237, 93-115.

26. Husein-ElAhmed H., Gieler U., Steinhoff M.: Lichen planus: a comprehensive evidence-based analysis of medical treatment. J Eur Acad Dermatol Venereol 2019, 33, 1847-1862.

27. Ahluwalia A.: Topical glucocorticoids and the skin-mechanisms of action: an update. Mediators Inflamm 1998, 7, 183-193.

28. Ling T.C., Gibbs N.K., Rhodes L.E.: Treatment of polymorphic light eruption. Photodermatol Photoimmunol Photomed 2003, 19, 217-227.

29. Cribier B., Frances C., Chosidow O.: Treatment of lichen planus. An evidence-based medicine analysis of efficacy. Arch Dermatol 1998, 134, 1521-1530.

Received: 1.11.2021

Accepted: 8.12.2021

Otrzymano: 1.11.2021 r.

Zaakceptowano: $8.12 .2021 \mathrm{r}$.

How to cite this article

Buczyńska W., Popow A., Nowowiejska J., Baran A., Flisiak I.: Atypical coexistence of polymorphous light eruption and eruptive lichen planus in a patient with necrobiosis lipoidica. Dermatol Rev/Przegl Dermatol 2021, 108, 407-413.

DOI: https://doi.org/10.5114/dr.2021.113158 